\title{
Tuhan dalam Basic Concept of the Quran: Pembacaan atas Pemikiran Maulana Abul Kalam Azad
}

\author{
Za'im Kholilatul Ummi \\ UIN Sunan Kalijaga Yogyakarta \\ e-mail: zaimkummi@icloud.com
}

\begin{abstract}
Studying aspects of God in religion is an important thing that must be understood. Studying the concept of God in a religion can lead people to understand religion and about values as a guide for human life. Explanation of God has experienced a long journey, is Maulana Abul Kalam Azad, a modern Islamic thinker from India, one of those who tried to explore the meaning of God. Coming from a very conservative family, Azad then tried to break away from that thinking towards modern thinking. This influenced Azad in his thinking and produced a new view of God in his interpretation, Tarjuman al-Qur'an. In this paper we will discuss the meaning of God in Surah al-Fatihah which according to Azad in it is the main content of the Koran, in the book Basic Concept of the Quran, a summary book Tarjuman al-Qur'an Azad about the interpretation of Surah al-Fatihah. The meaning of God carried out by Azad was found in his interpretation of Surah al-Fatihah with the conclusion that God has three distinct but interrelated attributes namely rububiyyah, rahmah, and 'are. Azad's reading of the Qur'an was carried out using a textual-theological approach and a comparative approach to religion.
\end{abstract}

Keywords: God, Basic Concept of the Quran, Methods and Approaches, Maulana Abul Kalam Azad.

\begin{abstract}
Abstrak
Mempelajari aspek ketuhanan dalam beragama adalah sebuah hal penting dan hal yang harus dipahami. Mempelajari konsep ketuhanan dalam sebuah agama dapat mengantarkan manusia dalam memahami agama dan mengenai nilai sebagai petunjuk bagi kehidupan manusia. Penjelasan mengenai tuhan telah mengalami perjalanan panjang, adalah Maulana Abul Kalam Azad, pemikir Islam modern dari India, salah satu di antara orang yang berusaha mengupas makna tuhan. Berasal dari keluarga yang sangat konservatif sehingga kemudian Azad berusaha untuk lepas dari pemikiran tersebut menuju pemikiran yang modern. Hal ini yang mempengaruhi Azad dalam pemikirannya dan menghasilkan pandangan baru mengenai tuhan dalam tafsirnya, Tarjuman al-Qur'an. Dalam makalah ini akan dibahas makna Tuhandalam surat al-Fatihah yang menurut Azad di dalamnya adalah isi pokok al-Qur'an, di dalam buku Basic Concept of the Quran yaitu buku ringkasan Tarjuman al-Qur'an Azad tentang tafsir surat al-Fatihah. Pemaknaan tuhan yang dilakukan oleh Azad diterdapat dalam penafsirannya terhadap surat al-Fatihah dengan kesimpulan bahwa tuhan memiliki tiga sifat berbeda namun saling memiliki keterikatan yaitu rububiyyah, rahmah, dan 'adalah. Pembacaan Azad terhadap al-Qur'an dilakukannya dengan menggunakan pendekatan tekstualteologis dan pendekatan perbandingan agama.
\end{abstract}

Kata Kunci: Tuhan, Basic Concept of the Quran,Metode dan Pendekatan,Maulana Abul Kalam Azad. 


\section{Pendahuluan}

Anggapan dasar bahwa jika seseorang ingin memahami atau menjelaskan suatu agama, orang itu harus tahu sejarah asal usulnya. ${ }^{1}$ Dalam beragama, tuhan adalah adalah unsur paling penting yang harus dipahami. Pembahasan mengenai tuhan selalu mengalami perkembangan seiring dengan berkembangnya permasalahan dan pemikiran manusia. Tuhan adalah sang pencipta dan pemelihara manusia dan semua makhluk yang ada di alam semesta. Di dalam al-Qr'an, kata tuhan dengan berbagai bentuk katanya disebutnya berulang-ulang kali.

Meskipun demikian, al-Qur'an yang merupakan sumber sekaligus kitab yang sepenuhnya ditujukan kepada manusia, bukanlah kitab tentang tuhan dan bukan kitab yang khusus berbicara tentang tuhan. Bagi al-Qur'an eksinstensi tuhan bersifat sangat fungsional. Secara khusus Dia memberi petunjuk kepada manusia dan kelak akan mengadilinya. ${ }^{2}$

Penafsiran mengenai kata tuhan di dalam al-Qur'an telah banyak dilakukan dan telah mengalami sejarah panjang. Mulai dari kajian tentang tuhan dari masa

\footnotetext{
1 Jam'anuri,Agama Kita: Perspektif Sejarah Agamaagama (Sebuah Pengantar), Cet-II(Yogyakarta: Kurnia Kalam, 2002), 18.

2 Fazlur Rahman, Tema Pokok al-Qur'an, terj. Ervan Nurtawab dan Ahmad Baiquni (Bandung: PT Mizan Pustaka, 2017), 2.
}

klasik hingga kontemporer. Salah satu yang membahas mengenai pemaknaan tuhan di dalam al-Qur'an adalah Maulana Abul Kalam Azad, seorang pemikir muslim modern dari India. Azad memberikan penafsiran dengan sauasana baru mengenai al-Qur'an di dalam karya tafsirnya.

Penulis akan difokuskan pada bahasan mengenai latar belakang pemikiran Maulana Abul Kalam Azad, dan bagaimana pemikiran Azad mengenai tuhan dalam Basic Concept of the Quran. Basic Concept of the Quran adalah sebuah karya yang merupakan hasil rangkuman dari penafsiran Azad terhadap surat AlFatihah.

\section{Biografi Abul Kalam Azad}

Maulana Abul Kalam Azad, selanjutnya disebut Azad, lahir di kota Makkah. Nama aslinya adalah Muhyiddin Ahmad. Namun kemudian ia menggantinya menjadi Azad yang berarti bebas yang kemudian dipakai sampai akhir hayatnya. Penggantian nama yang Azad lakukan adalah sebagai simbol kebebasan berpikir. Azad lahir dari keluarga yang aktif mengadakan pembaharuan di India. ${ }^{3}$

3 Taufik Mandailing, Maulana Abul Kalam Azad Muslim Nasionalis India, cet-II(Yogyakarta: Goen's Media, 2013), 60 . 
Pada saat kecil Azad dididik oleh ayahnya sendiri, Khairuddin Dihlawi, seorang tokoh sufi yang tidak bisa menerima perubahan, dalam lingkungan yang sangat konservatif. Ayahnya adalah seseorang yang sangat tradisional dan beranggapan bahwa pendidikan yang modern itu dapat membawa kehancuran. Oleh Karena itu Azad dididik langsung oleh ayahnya dengan bantuan beberapa ulama teman dekat ayahnya yang mengajarnya dengan pendidikan tradisional yang sangat ketat. Azad adalah anak yang memiliki kecerdasan yang luar biasa. Dari guru-gurunya tersebut Azad belajar Bahasa Arab, Persia, Filsafat, Logika, Aritmatika, dan Sejarah dengan sangat cepat, yang biasanya diselesaikan dalam masa empat belas tahun namun Aazad dapat menempuhnya hanya dalam masa empat tahun saja. ${ }^{4}$

Azad dibesarkan dalam lingkungan keluarga yang sangat konservatif. Keluarga Azad adalah keluarga sufi yang sangat fanatik dalam memahami dan menjalankan agama. Meskipun begitu, dalam perkembangan intelektualnya Azad sangat ingin keluar dari kungkungan pemikiran yang selama ini telah diajarkan oleh keluarganya. Azad mengaku bahwa ia banyak dipengaruhi

4 Taufik Mandailing, Maulana Abul Kalam Azad Muslim Nasionalis India, 62. oleh pemikiran Sayyid Ahmad Khan ${ }^{5}$ dalam perkembangannya ini karena bagi Azad hal ini merupakan sebuah pengalaman yang membebaskan pemikiran konservatifnya. Azad sangat mengidolakan Sayyid Ahmad Khan dan menyebutnya sebagai Mujtahin yang brilian (Mujtahid-e-mutlak) dan berambisi untuk menulis karya-karya nya dalam bentuk yang sama seperti Sayyid Ahmad Khan. Dari sini dapat dipahami bahwa dalam perkembangannya, pemikiran Azad sangat bertolak belakang dengan apa yang diajarkan oleh ayahnya pada saat kecil. 6

Azad tidak menyangkal bahwa latar belakang pemikirannya banyak dipengaruhi oleh Sayyid Ahmad sehingga ia terinspirasi untuk menguasai bahasa Inggris. Azad banyak membaca teks-teks bible dan referensi sejarah dan filsafat yang menggunakan bahasa Inggris.

5 Sayyid Ahmad Khan adalah seorang yang sangat rasional, dan teologinya dipengaruhi oleh para filsuf Yunani dan teolog Mu'tazilah. Sayyid ahmad Khan mendirikan aliran Aligarh. Ide-ide yang dikembangkan oleh Sayyid Ahmad Khan dalam perguruan Aligarh tersebut meniru model sekolah Inggris dengan menggunakan bahasa pengantar bahasa Inggris dan juga tenaga pengajat Inggris yang mengajarkan ilmu-ilmu pengetahuan modern sebagai khasnya. Perguruna ini menjadi penggerak utama dalam pembaharuan pemikiran bagi kalangan umat muslim di India. Dari pemikiranpemikiran yang di kembangkan di perguruan ini kemudian muncul tokoh-tokoh pembaharuan seperti Amir Ali, Muhammad Iqbal, Syibli, dan Maulana Abul Kalam Azad. Lihat Taufik Mandailing, Maulana Abul Kalam Azad Muslim Nasionalis India, 65. Lihat juga Harun Nasution, Pembaharuan dalam Islam: Sejarah Pemikiran dan Gerakan (Jakarta: Bulan Bintang, 1996), 188.

${ }_{6}$ Taufik Mandailing, Maulana Abul Kalam Azad Muslim Nasionalis India, 65. 
Pengaruh dari tokoh-tokoh idolanya juga banyaknya bacaan yang beragam ini kemudian berpengaruh terhadap pemikiran Azad sebagai tokoh yang berpengaruh di India terutama dalam masalah keagamaan dan politik. ${ }^{7}$

Azad mulai memasuki dunia politik dengan banyak melakukan hubungan dengan aktivis-aktivis pergerakan kemerdekaan di India. Pada mulanya kehadiran Azad pertama kali di tengah-tengah mereka disambut dengan kecurigaan. Hal ini dikarenakan sebagian besar mereka adalah orang-orang Hindu kelas menengah yang direkrut secara khusus dan telah menganggap Islam dan Muslim sebagai kaki tangan penjajah musuh mereka. Namun pada akhirnya Azad berhasil meyakinkan mereka untuk tidak menggeneralisir fakta yang ada, karena penjajah adalah musuh bersama mereka sebagai manusia dan orang India yang mendambakan kemerdekaan. Azad kemudian berusaha untuk mendekati para aktivis Muslim di daerah Bengal dan Bihar

7 Selain Sayyid Ahmad Khan, Azad juga benyak terinspirasi oleh Muhammad Syibli, seorang pengikut Syeh Waliyullah yang juga merupakan salah satu pengajar di Aligarh dan Madrasah Nadwah al-Ulama di Lucknow yang banyak bersentuhan dengan dunia pendidikan dan menjalin pergaulan yang baik dengan anak muda Muslim sebagai media untuk menyalurkan ide pemikirannya. Meskipun Syibli adalah termasuk seorang yang rasionalis dan salah satu murid Sayyid Khan namun pada beberapa hal tertentu ia berbeda dengan Sayyid Khan. Lihat Taufik Mandailing, Maulana Abul Kalam Azad Muslim Nasionalis India, 65-67. dan meyakinkan mereka akan perjuangan bersama tersebut. ${ }^{8}$

Sebagai orang yang gemar membaca dan menulis, Azad adalah orang yang produktif. Azad menulis karya tulis yang sangat banyak, di antara banyaknya karya yang ia tulis. Azad menulis tiga karya biografi tentang kehidupannya. Di samping iu, tulisan Azad juga tersebar dalam berbagai majalah. Di antara karyakaryanya, ada satu karya tafsir al-Qur'an yang ditulis menggunakan Bahasa Urdu, yaitu tafsir Tarjuman al-Qur'an, ini adalah karya terbaik Azad. Karyanya ini kemudian diterjemahkan oleh Syed Abdul Latif. Tafsir ini terdiri dari tiga volume. Volume pertama berisikan pembukaan surat al-Fatihah yang menurut Azad merupakan pengenalan terhadap pokok atau inti dari al-Qur'an, semua konsep dasar al-Qur'an yang diturunkan semua ada dalam surat ini. Dalam volume kedua Azad menafsirkan surat al-Baqarah sampai surat al-Anfal. Sedangkan volume yang ketiga berisikan penafsiran Azad dari surat al-Taubah sampai surat al$\mathrm{Mu}^{\prime}$ minun. ${ }^{9}$

Selain itu Azad juga banyak menulis di berbagai majalah yang terbit di

8 Ahmad Rafiq, "Kesatuan Tuhan dan Kesatuan Agama: Studi Atas Pemikiran Mawlana Abu al-Kalam Azad", Jurnal Studi Ilmu-ilmu al-Qur'an dan Hadis Vol. 2, No. 1, Juli 2001, 38.

9 Taufik Mandailing, Maulana Abul Kalam Azad Muslim Nasionalis India, 79. 
India dan juga menuliskan karya biografi dirinya tentang perjalanan hidup yang ia lalui. Bahkan Ian Handerson Dauglas menyebutkan bahwa paling tidak Azad memiliki 135 karya. 117 karya di dalam bahasa Urdu, Persia, dan Arab, dan 12 karya lainnya menggunakan bahasa Inggris yang tersebar di dalam enam majalah. ${ }^{10}$

\section{Makna Tuhan dalam Basic Concept of the} Quran

\section{Maulana Abul Kalam Azad} berargumen bahwa konsep tuhan yang paling primitif adalah monoteisme. Meskipun pada awalnya makna tuhan belum dirumuskan seperti sekarang setelah megalami perkembangan. Pada saat itu manusia mempercayai satu sosok yang dianggap paling dominan dan paling tinggi kepemimpinannya yang menciptakan dan mengatur jalannya alam semesta. ${ }^{11}$

10 Taufik Mandailing, Maulana Abul Kalam Azad Muslim Nasionalis India, 79-80.

${ }_{11}$ Azad berpendapat bahwa manusia pada masa itu menganggap tuhan sebagai God of Awe and Terror. Dikarenakan konsep ketuhanan mereka masih terpengaruh oleh keadaan lingkungan dan kondisi kehidupan mereka, seperti Guntur, petir, letusan gunung, gempa bumi, badai, dan banjir. Dari kejadian ini kemudian manusia berpikir bahwa ada terror dan adanya fenomena bencana alam sebagai bentuk atau bagian ikut campur tuhan. Meraka beranggapan bahwa meraka adalah manusia yang lemah dan kondisi di sekitar mereka seakan-akan ingin menghancurkan mereka seperti binatang buas yang akan menerkam. Lihat Maulana Abul Kalam Azad, Basic Concept of The Qur'an: Being a Resume of The Views Advanced by him in his commentary in Urdu of the Surat_ul_Fatiha the Opening Chapter of the Qur'an, 2.
Seiring

berkembangnya peradaban, yang pada mulanya manusia primitif yang menganut paham monoteisme, berubah menjadi politeisme dan antropomorpisme, yaitu mereka menyandangkan sifat manusia kepada tuhan. Hal ini dikarenakan tuhan yang mereka sembah jauh dari kehidupan mereka. Sehingga mereka membuat sendiri bentuk sesembahan sebagai tuhan mereka. ${ }^{12}$

Selanjutnya kepercayaan manusia dari penyimpangan ketuhanan yang telah dilakukan kembali lagi seperti pada masa sebelumnya, yaitu politeisme berubah kembali menjadi monoteisme, dan antropomorpisme menjadi transendentalisme. Jika sebelumnya manusia menganggap tuhan sebagai bentuk dari terror alam, disini tuhan yang mereka kenal adalaha tuhan yang penuh kasih sayang. Meskipun pada fase ini manusia masih menganggap bahwa tuhan memiliki sifat kemanusiaan. ${ }^{13}$

Sebelum al-Qur'an diturunkan, tingkat tertinggi yang dapat dicapai oleh manusia dapat membayangkan tuhan tanpa ada bantuan lambang apapun. Akan

12 Maulana Abul Kalam Azad, Basic Concept of The Qur'an: Being a Resume of The Views Advanced by him in his commentary in Urdu of the Surat_ul_Fatiha the Opening Chapter of the Qur'an, 3.

${ }_{13}$ Maulana Abul Kalam Azad, Basic Concept of The Qur'an: Being a Resume of The Views Advanced by him in his commentary in Urdu of the Surat_ul_Fatiha the Opening Chapter of the Qur'an, 4. 
tetapi dalam hal sifat-sifat tuhan belum ada yang dapat memberikan gambaran. Bahkan bangsa Yahudi ataupun Yesus Kristus sendiri dalam berbicara mengenai ketuhanan dan pengampunan mereka menggunakan persamaan semu. Selanjutnya, al-Qur'an dating denga keistimewaanya, ia menyingkap tabir persamaan semu engan kondisi manusia dari citra tuhan dan memungkinkan kita untuk mengambil sudut pandang yang melampaui pengalaman manusia mengenai tuhan dan sifat-sifatnya.

“Tidak ada sesuatupun yang serupa dengan Dia" (Q.S. alSyura: 11)

"Dia tidak dapat dicapai oleh penglihatan mata, sedangkan Dia dapat melihat segala penglihatan itu dan Dialah Maha Halus, Maha teliti" (Q.S. al-An'am: 103)

"Katakanlah Muhammad, 'Dialah Allah yang Maha Esa'. Allah tempat meminta segala sesuatu. (Allah) tidak beranak dan tidak pula diperanakkan. Dan tidak ada sesuatu yang disetarakan dengan Dia" (Q.S. al-Ikhlas: 1-4)

Ketika memahami makna tuhan dalam al-Qur'an, Azad menafsirkan surat al-Fatihah sebagai objek kajiannya. Sebagaimana yang telah disebutkan di atas bahwa menurut Azad pemahaman yang didapat di dalam surat ini dapat memberikan kita gambaran terhadap pemahaman al-Qur'an seluruhnya.
Azad dalam menafsirkan surat alFatihah ayat al-hamd li Allah rabb al-alamin dengan memahami aspek kemanusiaan dari ayat ini. Pujian yang dimaksud ditujukan hanya kepada Allah. Pembatasan tersebut secara manusiawi bertujuan mengingatkan hati dan pikiran manusia akan kekuatan luar biasa yang mengatasi seluruh makhluk, sehingga seluruh aktivitas kehidupan pun hanya tertuju pada-Nya. Penafsiran ini kemudian dikuatkannya dengan Q.S. Ali Imran ayat 191.14

Kekuatan tersebut berhubungan dengan penggunaan kata Allah dalam menyebutkan tuhan. Dengan melakukan serangkaian kajian dan perbandingan terhadap bahasa-bahasa dalam rumpun semit lainnya, seperti Hebrew, Syria, Aramiya, Chaldea, Himyar dan Arab, semuanya mempunyai kesamaan huruf dasar dalam menyebut Tuhan yaitu A, L dan H. Azad memberikan kesimpulan bahwa kata Allah dalam bahasa Arab adalah ungkapan manusia yang bisa mewakili kebesaran tuhan atas kekuasaanNya. Terma ini berbeda dengan ungkapan sifat-sifat Tuhan lainnya yang hanya

${ }^{14}$ Ahmad Rafiq, "Kesatuan Tuhan dan Kesatuan Agama: Studi Atas Pemikiran Mawlana Abu al-Kalam Azad", 44. 
mewakili satu kekuatan tertentu yang dimiliki oleh tuhan. 15

Sifat-sifat tuhan yang dimaksudkan oleh Azad adalah Rabb alalamin, al-rahman, al-rahim, dan malik yaum al-din. Dari empat term tersebut kemudian dikategorikan dalam tiga istilahdalam penafsirannya, sebagai berikut:

1. Rububiyyah (The Attribute of Providence)

Pemaknaan rububiyyah bagi Azad disini tidak hanya diartikan sebagai pengasuhan secara sempit. Kata ini adalah turunan dari kata rabb yang dalam bahasa Ibrani, Syiria, dan Arab berarti memberi makan atau sarana untuk mempertahankan hidup. ${ }^{16}$

Rububiyat is thus a continuous process of providing one with all that one need in every situation and at every stage. The view with the Quran presents of God as Rabb may now be easily grasped. Rabbul alamin is the attribute which the Quran applies to God in his rolw of Rabb. It points out in a striking manner that God is not the Rabb or nourisher of any particular community or class, but that he is the Rabb of all mankind, and

${ }^{15}$ Ahmad Rafiq, "Kesatuan Tuhan dan Kesatuan Agama: Studi Atas Pemikiran Mawlana Abu al-Kalam Azad", 44. Lihat juga Maulana Abul Kalam Azad, Basic Concept of The Qur'an: Being a Resume of The Views Advanced by him in his commentary in Urdu of the Surat_ul_Fatiha the Opening Chapter of the Qur'an, 14-16.

16 Abdul Kalam Azad, Konsep Dasar al-Qur'an (Jakarta: Pustaka Firdaus, 1991), 27. of everything that subsists in the universe. ${ }^{17}$

Rububiyyah adalah sebuah proses yang berlangsung secara terus menerus yang memberikan segala sesuatu yang diperhatikan dalam setiap keadaan dan setiap tahap. Dapat dipahami bahwa tuhan bukan hanya Rabb bagi suatu masyarakat atau kelompok tertentu tetapi Dia adalah tuhan bagi seluruh umat manusia dan juga bagi segala sesuatu yang ada di bumi ini.

2. Rahmah (The Attribute of Graciousness)

Bagi Azad sifat rahmah ini merupakan suatu kenyataan yang menakjubkan dalam kehidupan yang lebih dari sifat rububiyyah sebelumnya. Rahmah dapat diartikan sebagai kasih atau ampunan tuhan terhadap semua makhluk ciptaannya. Dijelaskan bahwa prinsip rahmah tercantum di awal surat al-Fatihah, dalam pernyataan "Bismillahi al-rahman alrahim". Kata al-rahman dan al-rahim adalah turunan dari kata rahmah yang diartikan sebagai jenis kasih

17 Maulana Abul Kalam Azad, Basic Concept of The Qur'an: Being a Resume of The Views Advanced by him in his commentary in Urdu of the Surat_ul_Fatiha the Opening Chapter of the Qur'an, 21. 
kasang yang tulus kepada orang lain yang meliputi aspek cinta, rasa sayang, dan kemurahan hati. ${ }^{18}$

3. 'Adalah (The Attribute of Justice)

Sifat 'adalah, di dalam al-Qur'an disebutkan, merupakan kelanjutan dari sifat rububiyyah dan sifat rahmah. Adl adalah keadilan yang juga digunakan dalam pengertian timbangan yang menunjukkan berat yang sama dan seimbang di kedua sisi. Prinsip inilah yang bertanggung jawab atas keindahan dan perbandingan dalam segala bentuk dan pemikiran, dan menjadi pijakan dasar manusia. Dari prinsip inilah yang menyatukan suatu masyarakat. ${ }^{19}$

Dari ketiga sifat yang telah disebutkan di atas, dapat dipahami bahwa menurut Azad ketiganya merupakan sifat yang berbeda namun memiliki satu kesatuan yang sama. Hal tersebut didasarkan pada subjek yang disifatinya, yaitu tunggal.

Selanjutnya adalah penafsiran Azad terhadap ayat iyyaka na'budu wa iyyaka nasta'in. Selain dimaknai sebagai

18 Maulana Abul Kalam Azad, Basic Concept of The Qur'an: Being a Resume of The Views Advanced by him in his commentary in Urdu of the Surat_ul_Fatiha the Opening Chapter of the Qur'an, 122.

${ }_{19}$ Maulana Abul Kalam Azad, Basic Concept of The Qur'an: Being a Resume of The Views Advanced by him in his commentary in Urdu of the Surat_ul_Fatiha the Opening Chapter of the Qur'an, 78. keesaan Allah, juga dipahami sebagai adanya kesatuan tuhan dan seluruh makhluk hidup yang ada di bumi. Hal ini berdasarkan pada data-data antropologis manusia-manusia terdahulu. Azad menyimpulkan bahwa pada dasarnya seluruh umat manusia itu tunduk pada satu kekuatan yang luar biasa dan sama yang mampu mengatasi kehidupan mereka. Jadi sebenarnya semuanya diarahkan kepada satu kekuatan yang tidak dapat dinalar oleh manusia. Dengan demikian, Azad berkesimpulan bahwa seluruh umat mansuia dari generasi ke generasi adalah penganut monoteisme (bertuhan satu). Kesimpulan tersebut dikuatkannya dengan Q.S. al-Taubah ayat 19 dan al-Baqarah ayat 203.20

Dari penjelasan di atas mengenai kesatuan tuhan, menurut Azad pada dasarnya semua agama adalah satu. Yang menjadi perbedaan diantaranya adalah 'sampul' agama yang terbentuk karena adanya pengaruh lingkungan dan pemikiran dari pada pendahulunya. Karena secara evolutif manusia seluruhnya berasal dari asal yang sama, kemudian terjadi perpecahan karena adanya pengaruh-pengaruh dari luar. Selanjutnya manusia dingatkan lagi atas

${ }^{20}$ Ahmad Rafiq, "Kesatuan Tuhan dan Kesatuan Agama: Studi Atas Pemikiran Mawlana Abu al-Kalam Azad", 48. Lihat juga Mawlana Abul Kalam Azad, Basic Concept of The Qur'an, 82. 
bimbingan tuhan untuk kembali menjadi satu. Demikianlah proses yang diajarkan oleh semua manusia. ${ }^{21}$

\section{Maulana Abul Kalam Azad dan Penafsirannya}

Maulana Abul Kalam Azad adalah seorang pemikir muslim modern dari India. Azad menyusun tafsirnya terhadap al-Qur'an dengan mempertimbangkan realitas yang terjadi di India. Ia berpandangan bahwa setiap orang dengan pikirannya merupakan bentukan dari lingkungan dan zamannya masingmasing, termasuk para penafsir dalam menghasilkan karya tafsirnya. ${ }^{22}$

Dengan asumsi di atas, Azad kemudian membedakan penafsiran yang dilakukan oleh sahabat dan penafsiran yang muncul setelah masa itu. Menurut Azad penafsiran yang dilakukan para sahabat bebas dari asumsi yang telah disebutkan sehingga pemaknaan ang didapatkan dari penafsiran adalah pemaknaan sesuai dengan hakikat yang dikandung oleh al-Qur'an. Hal ini disebabkan kedekatan para sahabat dengan Nabi sehingga mereka dapat menanyakan langsung kepada Nabi

${ }^{21}$ Ahmad Rafiq, "Kesatuan Tuhan dan Kesatuan Agama: Studi Atas Pemikiran Mawlana Abu al-Kalam Azad", 45.

${ }^{22}$ Ahmad Rafiq, "Kesatuan Tuhan dan Kesatuan Agama: Studi Atas Pemikiran Mawlana Abu al-Kalam Azad", 40. perihal penjelasan dan pemaknaan suatu ayat. Keadaan ini dipandang bisa mengalahkan pengaruh lingkungan dan peradaban saat itu. ${ }^{23}$

Berbeda dengan pandangannya terhadap penafsiran sahabat, penafsiran pada generasi setelahnya telah mengalami kemunduran untuk menangkap makna hakiki karena telah banyak terpengaruh oleh lingkungan dan kondisi zaman mereka. Oleh karena itu hasil penafsiran di antar keduanya sangat berbeda. Hal tersebut yang dijadikan sebagai alas an oleh Azad ketika mengecualikan generasi sahabat pada penafsiran yang selalu mengalami keberpihakan kondisi atau keadaan lingkungan dari penafsir.

Azad juga mengkritik para penafsir yang menafsirkan al-Qur'an secara rasional. Menurutnya Nabi Muhammad saw. sebagai penerima wahyu bukanlah orang yang ahli debat dengan rasional sehingga pesan-pesan alQur'an yang disampaikan tidak patut untuk diperdebatkan. Karena al-Qur'an diperuntukkan kepada manusia sehingga pesan-pesannya bias ditangkap oleh rasa kemanusiaan yang mana lebih daripada akal. Azad membatasi penafsiran bi al-ra'yi bukan untuk menangkap makna hakikat

${ }^{23}$ Ahmad Rafiq, "Kesatuan Tuhan dan Kesatuan Agama: Studi Atas Pemikiran Mawlana Abu al-Kalam Azad", 41. 
dari al-Qur'an. Selain kondisi lingkungan, hal-hal yang menjadi pengaruh terhadap degradasi penafsiran setelah sahabat menurut Azad adalah adanya pengaruh dialektika dalam filsafat sehingga memengakibatkan kekaburan makna dari istilah-istilah tertentu di dalam al-Qur'an dan kecenderungan para penafsir terhadap suatu golongan atau mazhab tertentu. ${ }^{24}$

Azad sendiri menyusun tafsirnya untuk mendapatkan makna yang terkandung di dalam al-Qur'an dengan mempertimbangkan kondisi lingkungan yang pada saat itu terjadi di India. Kitab tafsir yang ditulis oleh Azad adalah Tarjuman al-Qur'an yang bertujuan untuk menyampaikan nilai-nilai dan pesanpesan di dalam al-Qur'an kepada manusia umumnya. Azad memfokuskan kajiannya pada surat al-Fatihah yang diyakini Azad di dalamnya terangkum nilai-nilai alQur'an secara keseluruhan. ${ }^{25}$

Metode yang dilakukan oleh Azad dalam menafsirkan al-Qur'an adalah sebagai berikut:

1) Makna tekstual, yaitu pemahaman terhadap kata, istilah ataupun kalimat di dalam al-Qur'an

${ }^{24}$ Ahmad Rafiq, "Kesatuan Tuhan dan Kesatuan Agama: Studi Atas Pemikiran Mawlana Abu al-Kalam Azad", 42-43.

${ }^{25}$ Ahmad Rafiq, "Kesatuan Tuhan dan Kesatuan Agama: Studi Atas Pemikiran Mawlana Abu al-Kalam Azad", 43.
2) Generalisasi nilai-nilai dalam alQur'an yang memperlihatkan berbagai macam tujuan yang ingin dicapai oleh ayat-ayat tersebut

3) Memberikan argumen ataupun fakta-fakta yang dapat membantu dalam memahami ayat tersebut

4) Memberikan ayat-ayat lainnya yang sejalan dengan ayat yang ditafsirkan dan juga ayat yang mendukung nilai-nilai tersebut

5) Klarifikasi singkat atau kesimpulan terhadap pemaknaan suatu ayat.

Dengan tegas Azad menyatakan bahwa dalam proses penafsirannya Azad mengunakan metode tafsir al-Qur'an dengan al-Qur'an. Namun dalam menentukan hubungan antara satu ayat dengan ayat yang lain ia menggunakan pemahaman akalnya. Sehingga penafsirannya dapat dikategorikan sebagai tafsir bi al-ra'yi. ${ }^{26}$ Azad membatasi tafsir bi al-ra'yi hanya sampai pada memahami ayat dengan ayat yang lainnya saja dan mendukung makna ayat yang telah ada, bukan untuk mencari makna hakikat di dalam sebuah ayat atau makna hakiki. Meskipun Azad tidak menolak hadis, bahkan tetap menempatkannya sebagai

${ }^{26}$ Toipah, "Tafsir al-Qur'an atas Problematika Lintas Agama: Kajian atas Tafsir Tarjuman al-Qur'an Karya Mawlana Abul Kalam Azad", Jurnal Qof, Vol. 1 No. 1, Januari 2017, 70. 
sumber kedua ajaran Islam setelah alQur'an, dalam penafsirannya Azad cenderung mendahulukan penafsiran alQur'an dengan al-Qur'an melalui pemahaman rasional tentang hubungan antar ayat-ayat tersebut, sehingga sangat jarang kita temukan adanya kutipan hadis dalam karya tafsirnya. ${ }^{27}$

Azad tidak menjelaskan secara implisit pendekatan yang digunakannya dalam memahami al-Qur'an. Namun dapat dipahami bahwa pendekatan yang digunakan, sebagaimana argumen yang digunakan oleh Ahmad Rafiq, adalah:

1) Pendekatan tekstual-teologis

Dalam memberikan pemaknaan terhadap al-Qur'an, Azad menempatkan al-Qur'an sebagai kebenaran mutlak dari seluruh perjalanan manusia. Azad memulai penafsirannya terhadap al-Qur'an dengan menekankan kembali pemaknaan terhadap term-term al-Qur' an sesuai dengan makna asalnya berdasarkan pada pemahaman Azad terhadap ayat tersebut. Pemaknaan yang seperti ini lebih terkesan tekstual. Katakata di dalam al-Qur'an ia dimaknai oleh Azad sebagaimana

${ }^{27}$ Ahmad Rafiq, "Kesatuan Tuhan dan Kesatuan Agama: Studi Atas Pemikiran Mawlana Abu al-Kalam Azad", 41. makna asalnya dengan mengesampingkan konteks dari ayat tersebut. Pemaknaan yang seperti ini dapat dipahami sebagai pendekatan teksual-teologis yang mana menerima makna ayat tersebut dengan apa adanya dan menjadikan al-Qur;an sebagai kebenaran yang hakiki. ${ }^{28}$

2) Pendekatan perbandingan agama Selain pendekatan tekstualteologis, Azad juga menggunakan data-data dari agama lain dalam menguatkan argumennya mengenai tuhan yang telah ia paparkan. Dari data-data agama lain kemudian Azad membandingkannya dan kemudian diambil kesimpulan sesuai dengan idenya. Pendekatan yang seperti ini adalah pendekatan perbandingan agama. Namun sayangnya Azad terkesan tidak dibekali oleh sumber data untuk membandingkan dengan agama lain secara memadai. ${ }^{29}$

${ }^{28}$ Ahmad Rafiq, "Kesatuan Tuhan dan Kesatuan Agama: Studi Atas Pemikiran Mawlana Abu al-Kalam Azad", 52.

${ }^{29}$ Ahmad Rafiq, "Kesatuan Tuhan dan Kesatuan Agama: Studi Atas Pemikiran Mawlana Abu al-Kalam Azad", 52 


\section{Kesimpulan}

Dari pembahasan di atas, dapat dipahami bahwa Azad adalah seorang tokoh pemikir mulsim modern di India. Nama aslinya adalah Muhyiddin Ahmad. Namun kemudian ia menggantinya menjadi Azad yang berarti bebas yang kemudian dipakai sampai akhir hayatnya. Penggantian nama yang Azad lakukan adalah sebagai simbol kebebasan berpikir. Azad lahir dari keluarga yang aktif mengadakan pembaharuan di IndiaAzad merupakan orang yang memiliki peran penting dalam sejarah penafsiran India. Azad memberikan gagasan baru mengenai tuhan yang berbeda dengan para mufassir pendahulunya.

Secara umum, dalam bukuBasic Concept of the Qur'an, Azad menuliskan pemikirannya tentang sejarah ketuhanan, eksistensi tuhan, dan kesatuan tuhan dan kesatuan manusia. Azad berargumen pada dasarnya semua agama adalah satu. Yang menjadi perbedaan diantaranya adalah 'sampul' agama yang terbentuk karena adanya pengaruh lingkungan dan pemikiran dari pada pendahulunya. Karena secara evolutif manusia seluruhnya berasal dari asal yang sama, kemudian terjadi perpecahan karena adanya pengaruh-pengaruh dari luar. Selanjutnya manusia dingatkan lagi atas bimbingan tuhan untuk kembali menjadi satu. Demikianlah proses yang diajarkan oleh semua manusia.

Tuhan dalam surat al-Fatihah yang menurut Azad di dalamnya adalah isi pokok al-Qur'an, di dalam buku Basic Concept of the Quran yaitu buku ringkasan Tarjuman al-Qur'an Azad tentang tafsir surat al-Fatihah. Pemaknaan tuhan yang dilakukan oleh Azad diterdapat dalam penafsirannya terhadap surat al-Fatihah dengan kesimpulan bahwa tuhan memiliki tiga sifat berbeda namun saling memiliki keterikatan yaitu rububiyyah, rahmah, dan 'adalah. Pembacaan Azad terhadap al-Qur'an dilakukannya dengan menggunakan pendekatan tekstualteologis dan pendekatan perbandingan agama.

\section{Referensi}

1. Azad, Maulana Abul Kalam. Basic Concept of The Qur'an: Being a Resume of The Views Advanced by him in his commentary in Urdu of the Surat_ul_Fatiha the Opening Chapter of the Qur'an.New Delhi: Kitab Bhavan, 1996.

2. Dar, Muzafar Ahmad. "Role of Maulana Abul Kalam Azad in Hindu-Muslim-Unity during Freedom Struggle". International Journal of Innovative Knowledge Concept. Vol. 2. Issue 4. April 2016.

3. Jam'anuri. Agama Kita: Perspektif Sejarah Agama-agama (Sebuah Pengantar). Cet-II. Yogyakarta: Kurnia Kalam, 2002. 
4. Mandailing, Taufik. Maulana Abul Kalam Azad Muslim Nasionalis India. cet-II.Yogyakarta: Goen's Media, 2013.

5. Musthofa. "Kisah Ashab al-Kahf dalam Tarjuman al-Qur'an Karya Maulana Abul Kalam Azad". Skripsi Fakultas Ushuluddin UIN Sunan Kalijaga Yogyakarta, 2003.

6. Nasution, Harun. Pembaharuan dalam Islam: Sejarah Pemikiran dan Gerakan. Jakarta: Bulan Bintang, 1996.

7. Nur, Saleh. "Abdul Kalam Azad: Nasionalisme India". Jurnal Ushuluddin. Vol. XVI, No. 2, Juli 2010.

8. Rafiq, Ahmad. "Kesatuan Tuhan dan Kesatuan Agama: Studi Atas Pemikiran Mawlana Abu al-Kalam Azad". Jurnal Studi Ilmu-ilmu alQur'an dan Hadis. Vol. 2. No. 1. Juli 2001.

9. Rahman, Fazlur. Tema Pokok alQur'an. terj. Ervan Nurtawab dan Ahmad Baiquni. Bandung: PT Mizan Pustaka, 2017.

10. Sumanto, Edi. "Tuhan dalam Pandangan Filosuf (Studi Komparatif Arestoteles dengan AlKindi)." El-Afkar: Jurnal Pemikiran Keislaman dan Tafsir Hadis. Vol. 7. No. 12018.

11. Toipah. “Tafsir al-Qur'an atas Problematika Lintas Agama: Kajian atas Tafsir Tarjuman alQur'an Karya Mawlana Abul Kalam Azad". Jurnal Qof. Vol. 1 No. 1. Januari 2017. 